\title{
Influence of light on endocrine system and ovarian activity in the ocypodid crabs Ocypoda platytarsis and $O$. macrocera
}

\author{
K. Nadarajalingam \& T. Subramoniam* \\ Unit of Invertebrate Reproduction, Department of Zoology, University of Madras, Guindy Campus, Madras - 600 025, India
}

\begin{abstract}
Although photic stimulation represents an important extrinsic factor controlling reproduction in marine invertebrates, pertinent information is scanty for marine crustaceans. We investigated light-induced biochemical changes in ovary, hepatopancreas, muscle and haemolymph of the ocypodid crabs Ocypoda platytarsis and O. macrocera in order to determine metabolic changes during ovarian maturation under altered light intensities. Increased light intensity caused acceleration of oocyte maturation in $O$. macrocera but no appreciable change in oogenetic activity of $O$. platytarsis; however, there was a sudden rise in metabolic activity of ovary, hepatopancreas and muscles in both crabs. Cytological observations indicated hypertrophy of connective tissue and follicle cells in the ovary of $O$. platytarsis. In both crabs eyestalk neurosecretory cells (NSC) showed more secretory activity under elevated light intensity. A corresponding increase in secretory activity of the NSC of brain and thoracic ganglion was evident solely in $O$. macrocera. Increased secretory activity of NSCs in brain and thoracic ganglion of $O$. macrocera is suggested to be responsible for the acceleration in oocyte maturation. The differences in the reproductive response to photic stimulus of the 2 crabs may be related to their different breeding habits.
\end{abstract}

\section{INTRODUCTION}

Environmental influences on reproduction in marine invertebrates are well investigated (Kinne 1970, 1971, 1972, Giese \& Pearse 1974). Among the important factors that control reproduction are temperature, salinity and photoperiod (e.g. Stephens 1952, Aiken 1969a, b, Armitage et al. 1973, Pradeille-Rouquette 1976a, b, Steel et al. 1977, Pillay \& Ono 1978, McQueen \& Steel 1980). However, there is paucity of definitive experimental evidence. In stalk-eyed decapod crustaceans, environmental changes are entrained in the neurosecretory centres of eyestalk, and probably brain (e.g. Fingermann \& Oguro 1962, Konok 1962, Vitez 1973, Van Herp et al. 1977).

We have studied light-intensity effects on neurosecretory centres as well as ovarian functions in the crabs Ocypoda platytarsis and O. macrocera. Although photic stimulation represents an important extrinsic factor controlling reproduction in marine invertebrates

- Addressee for correspondence; present address: c/o Wallis Clark, Bodega Marine Laboratory, University of Califomia, Davis, Bodega Bay, California 94923, USA
(Segal 1970), not much information is available on marine crustaceans. The information available on photoperiodic effects on reproduction in groups such as amphipods and isopods is also conflicting (Paris \& Pitelka 1962, Weiser 1963, Merriam 1971); hence, the primary objective of this paper is the study of neurosecretory as well as ovarian activities under different levels of light intensity.

\section{MATERIALS AND METHODS}

The 2 semiterrestrial supralittoral ocypodid crabs Ocypoda platytarsis (inhabiting coastal regions) and $O$. macrocera (living in estuarine shore regions) were collected from the Pulicat Lake, $53 \mathrm{~km}$ northeast of Madras University Campus (India). Crabs were collected by drag net and ring net. In the laboratory, they were kept separately in large cement tanks half-filled with clean sand and the remainder containing water collected from their respective habitats. Crabs were fed killed specimens of Emerita, Donax and Perna species. Water and sand were changed frequently. 
Classification of ovarian stages. Different stages of ovary development for biochemical assessment were recognised using the criteria listed in Tables $1 \& 2$.

Biochemical determination. Wet tissues were used in all estimations. Total protein was determined using the Ciocalteu method (Lowry et al. 1951); total free sugar, occurring as mono-, di- and oligosaccharides, by the anthrone method (Roe 1955); protein-bound sugar (PBS) by the method of Carroll et al. (1956) as adopted by Parvathy (1970). Glycogen was determined by the method of Carroll et al. (1956); ribonucleic acid (RNA) by the Dische \& Orcinol technique (Searcy \& MacInnis 1970a); de-oxyribonucleic acid (DNA) by the Burton diphenylamine technique (Searcy \& MacInnis 1970b).
The gravimetric method of Folch et al. (1957) was employed to quantify total lipid using chloroform and methanol as solvents.

Staining of neurosecretory cells (NSC) and their classification. Paraffin sections of formaldehyde-fixed eyestalk, brain and thoracic ganglia were stained with Gomori's (1939) chromehaematoxylin phloxine (CHP) and Gomori's (1950) paraldehyde fuchsin (PF) to demonstrate neurosecretory materials in the NSC. Types of NSC in the brain, thoracic ganglia and eyestalk were classified due to size, shape, location, tinctorial properties and cytological details.

Photoperiodism chamber. The rectangular-shaped photoperiodism chamber was made of wood $(193 \mathrm{~cm} \mathrm{~L}$

Table 1. Ocypoda platytarsis. Criteria for classification of ovarian stages during first reproductive cycle

\begin{tabular}{|c|c|c|c|}
\hline Ovarian stages & Colour of ovary & Condition of ovary & Cytological details \\
\hline $\begin{array}{c}\text { I } \\
\text { Immature }\end{array}$ & \multirow[t]{2}{*}{ Colourless } & \multirow[t]{2}{*}{ Thin and flimsy } & $\begin{array}{l}\text { Oogonial and follicle cells proliferated from } \\
\text { peripherally placed germarium }\end{array}$ \\
\hline & & & Follicle cells more in ovarian wall \\
\hline \multirow{4}{*}{$\begin{array}{l}\text { II } \\
\text { Vitellogenesis } \\
\text { I-A }\end{array}$} & \multirow[t]{4}{*}{ Light yellow } & \multirow{4}{*}{$\begin{array}{l}\text { Posterior arms unequal and } \\
\text { extend into abdomen }\end{array}$} & Oogonial cells in ovary center \\
\hline & & & $\begin{array}{l}\text { Previtellogenic oocytes possess round germinal } \\
\text { vesicle with } 1 \text { or } 2 \text { nucleoli }\end{array}$ \\
\hline & & & $\begin{array}{l}\text { Ooplasmic granules faintly stained with } \\
\text { haematoxylin }\end{array}$ \\
\hline & & & Few vitellogenic oocytes \\
\hline \multirow{2}{*}{$\underset{\substack{\text { III }-\mathrm{B} \\
\text { Vitellogenesis }}}{\cos }$} & \multirow[t]{2}{*}{ Yellowish orange } & \multirow[t]{2}{*}{$\begin{array}{l}\text { Deflected anterior arms } \\
\text { extend to gill chamber }\end{array}$} & $\begin{array}{l}\text { Previtellogenic oocytes encircled by layer of } \\
\text { follicle cells }\end{array}$ \\
\hline & & & $\begin{array}{l}\text { Vitellogenic oocytes deposited with eosinophilic } \\
\text { yolk droplets }\end{array}$ \\
\hline \multirow{3}{*}{$\begin{array}{l}\text { IV } \\
\text { Vitellogenesis } \\
\text { I-C }\end{array}$} & \multirow[t]{3}{*}{ Light orange } & \multirow{3}{*}{ Translucent and bulged } & Oocyte surrounded by flattened follicle cells \\
\hline & & & $\begin{array}{l}\text { Germinal vesicle oriented towards oocyte } \\
\text { periphery }\end{array}$ \\
\hline & & & $\begin{array}{l}\text { More eosinophilic yolk globules deposited in } \\
\text { ooplasm }\end{array}$ \\
\hline \multirow{3}{*}{$\begin{array}{c}\mathrm{V} \\
\text { Vitellogenesis } \\
\text { II-A }\end{array}$} & \multirow[t]{3}{*}{ Orange } & \multirow[t]{3}{*}{ Lobulated and opaque } & $\begin{array}{l}\text { More eosinophilic yolk globules in vitellogenic } \\
\text { oocyte }\end{array}$ \\
\hline & & & $\begin{array}{l}\text { The nucleus in vitellogenic oocyte starts } \\
\text { disappearing }\end{array}$ \\
\hline & & & $\begin{array}{l}\text { Previtellogenic oocytes arranged like piles of } \\
\text { coins between vitellogenic oocytes }\end{array}$ \\
\hline \multirow{3}{*}{$\begin{array}{l}\text { VI } \\
\text { Vitellogenesis } \\
\text { II-B }\end{array}$} & \multirow[t]{3}{*}{ Deep orange } & \multirow[t]{3}{*}{$\begin{array}{l}\text { Oocytes loosely packed in } \\
\text { thin ovarian wall }\end{array}$} & $\begin{array}{l}\text { Vitellogenic oocytes increase; previtellogenic } \\
\text { oocytes smaller and fewer }\end{array}$ \\
\hline & & & More yolk deposition \\
\hline & & & $\begin{array}{l}\text { Single-layered well-flattened follicle cells present } \\
\text { around oocyte }\end{array}$ \\
\hline \multirow[t]{4}{*}{$\begin{array}{l}\text { VII } \\
\text { Spent }\end{array}$} & \multirow[t]{4}{*}{ Colourless } & \multirow{4}{*}{$\begin{array}{l}\text { Flaccid with thick ovarian } \\
\text { wall and arms extending to } \\
\text { abdomen }\end{array}$} & $\begin{array}{l}\text { Unspawned oocytes phagocytosed by active, } \\
\text { bulged follicle cells }\end{array}$ \\
\hline & & & $\begin{array}{l}\text { Simultaneous with resorption, recuperation starts } \\
\text { by reactivation of germarium }\end{array}$ \\
\hline & & & $\begin{array}{l}\text { Newly proliferated oogonial cells in central } \\
\text { germarium }\end{array}$ \\
\hline & & & Ovulation scars in ovary \\
\hline
\end{tabular}


Table 2. Ocypoda macrocera. Criteria for classification of ovarian stages during first reproductive cycle

\begin{tabular}{|c|c|c|c|}
\hline Ovarian stages & Colour of ovary & Condition of ovary & Cytological details \\
\hline \multirow[t]{2}{*}{$\begin{array}{c}\text { I } \\
\text { Immature }\end{array}$} & \multirow[t]{2}{*}{ Colourless } & \multirow[t]{2}{*}{ Thin and flimsy } & $\begin{array}{l}\text { Oogonial and follicle cells proliferated from } \\
\text { peripherally placed germarium }\end{array}$ \\
\hline & & & $\begin{array}{l}\text { Follicle cells more in ovarian wall and encircle } \\
\text { growing oocytes }\end{array}$ \\
\hline \multirow{2}{*}{$\begin{array}{l}\text { II } \\
\text { Vitellogenesis } \\
\text { I-A }\end{array}$} & \multirow[t]{2}{*}{ Light yellow } & \multirow[t]{2}{*}{$\begin{array}{l}\text { Transparent and slightly } \\
\text { bulged }\end{array}$} & $\begin{array}{l}\text { Thick layer of follicle cells aound previtellogenic } \\
\text { oocyte }\end{array}$ \\
\hline & & & Few vitellogenic oocytes initiate yolk deposition \\
\hline \multirow[t]{2}{*}{$\underset{\text { IIII }}{\text { Vitellogenesis }}$} & \multirow[t]{2}{*}{ Light orange } & \multirow[t]{2}{*}{$\begin{array}{l}\text { Anterior arms bend } \\
\text { posteriolaterally and extend } \\
\text { to gill chamber }\end{array}$} & $\begin{array}{l}\text { Central germarium consists of spherical oogonial } \\
\text { cells with prominent nucleus containing chromatin } \\
\text { granules }\end{array}$ \\
\hline & & & $\begin{array}{l}\text { Previtellogenic oocytes either uni- or } \\
\text { binucleolated }\end{array}$ \\
\hline \multirow{2}{*}{$\begin{array}{l}\text { IV } \\
\text { Vitellogenesis } \\
\text { I-C }\end{array}$} & \multirow[t]{2}{*}{ Orange } & \multirow[t]{2}{*}{ Translucent, bulged } & $\begin{array}{l}\text { More eosinophilic yolk globules occur in vitellogenic } \\
\text { oocyte }\end{array}$ \\
\hline & & & Oocytes surrounded by well-flattened follicle cells \\
\hline \multirow{2}{*}{$\begin{array}{l}\text { V } \\
\text { Vitellogenesis } \\
\text { II-A }\end{array}$} & \multirow[t]{2}{*}{ Reddish orange } & \multirow[t]{2}{*}{ Lobulated and opaque } & $\begin{array}{l}\text { Yolk-globule deposition very rapid in vitellogenic } \\
\text { oocyte }\end{array}$ \\
\hline & & & Nucleus begins to disappear \\
\hline \multirow{3}{*}{$\begin{array}{l}\text { VI } \\
\text { Vitellogenesis } \\
\text { II-B }\end{array}$} & \multirow[t]{3}{*}{ Reddish brown } & \multirow{3}{*}{$\begin{array}{l}\text { Lobulated oocytes easily } \\
\text { dissociable due to thin } \\
\text { ovarian wall }\end{array}$} & Yolk deposition very rapid \\
\hline & & & $\begin{array}{l}\text { Single-layered, well-flattened follicle cells } \\
\text { separated from oocyte }\end{array}$ \\
\hline & & & Previtellogenic oocytes smaller and fewer \\
\hline \multirow{3}{*}{$\begin{array}{c}\text { VII } \\
\text { Spent }\end{array}$} & \multirow[t]{3}{*}{ Colourless } & \multirow[t]{3}{*}{ Flaccid and flabby } & More resorbed, unspawned oocytes \\
\hline & & & $\begin{array}{l}\text { Active follicle cells involved in resorption oval in } \\
\text { shape }\end{array}$ \\
\hline & & & Ovarian scars in ovary \\
\hline
\end{tabular}

$\times 140 \mathrm{~cm} \mathrm{~W} \times 148 \mathrm{~cm} \mathrm{H}$ ) and covered with thick black cloth. At the 4 corners of the upper side of the chamber, inverted ' $U$ ' shaped tubes were fixed for free aeration and temperature regulation. Three $4300 \mathrm{~K}$ fluorescent white tube lights were fixed inside the photoperiodism chamber on wooden pieces along with a pulley so that they could be moved up and down in order to adjust light intensity. The intensity was measured using an Eel lux meter.

Treatment of crabs. Ocypoda platytarsis and O. macrocera were placed in different cement tanks inside the photoperiodism chamber. Field salinity and environmental conditions were simulated in all tanks including controls. Crabs with Stage III ovaries were divided into 2 groups, one group serving as control, and other as experimental. Ovarian stages were assessed in live crabs using the window method of Gomez \& Nayar (1965), i.e. flapping out a rectangular piece of cuticle on the carapace for direct observation of the ovary. After observation, the exoskeleton was replaced and the wound sealed with molten wax together with a small amount of terramycin to prevent infection. One group of each species was subjected to a minimum light intensity of 0.02 to $0.036 \mathrm{~g} \mathrm{cal} \mathrm{cm}^{-2} \mathrm{~h}^{-1}$ as control (12 L : $12 \mathrm{D})$, and the experimental group was placed in the photoperiodism chamber with increased light intensities, e.g. 0.054 to $0.072,0.126$ to $0.151,0.216$ to $0.252,0.29$ to $0.36 \mathrm{~g} \mathrm{cal} \mathrm{cm}^{-2} \mathrm{~h}^{-1}$ under constant day length (12 L:12 D). Since positive responses of ovarian growth were obtained only in the intensity range of 0.29 to $0.36 \mathrm{~g} \mathrm{cal} \mathrm{cm}^{-2} \mathrm{~h}^{-1}$ all experiments were performed in this range.

Crabs were sacrificed at intervals of $5 \mathrm{~d}$. As marked changes in ovarian maturation were observed even on the 6th day in Ocypoda macrocera, the experiment was terminated on Day 6. O. macrocera is sensitive to laboratory rearing and it was difficult to maintain it for longer periods. In contrast, $O$. platytarsis is rather hardy and could be maintained in the laboratory for long periods. Also, since, no change was observed on Day 6 , the period of observation was extended to $16 \mathrm{~d}$. For control crabs, only Day 6 values are listed in the tables; the values obtained on Day 11 and 16 did not show any variation. For statistical analysis mean difference ' $t$ ' test (Bailey 1959) was used for comparison of biochemical constituents of controls and experimen- 
tals. Relative rate of biochemical fluctuation was calculated according to:

Relative rate of biochemical fluctuation $=$

Difference between mean biochemical value of control and experimental crabs

Biochemical value of control crab $\times 100$

\section{RESULTS}

\section{Influence of light intensity on biochemical constituents}

Light intensities of 0.29 to $0.36 \mathrm{~g} \mathrm{cal} \mathrm{cm}^{-2} \mathrm{~h}^{-1}$ accelerated ovarian maturation in Ocypoda macrocera within the $6 \mathrm{~d}$ experimental periods but not in $O$. platytarsis. Biochemical alterations during experimen tation were compared with controls of both species. Details of biochemical changes are given in Table 3 , and relative rates of fluctuation for $O$. platytarsis and O. macrocera in Tables 4 \& 5 respectively.

\section{Protein}

Ocypoda platytarsis. Ovarian protein increased $(+31.11 \%)$ with a corresponding decline in hepatopancreatic protein $(-18.31 \%)$ on Day 6 . Haemolymph protein $(+108.60 \%)$ as well as muscle protein $(+36.92 \%)$ showed marked increases during this period. On Day 11 all organs revealed a rise. However, on Day 16 ovary protein $(-32.22 \%)$ and hepatopancreas $(-18.31 \%)$ declined considerably, in contrast to a continued rise in muscle $(+24.62 \%)$ and haemolymph $(+54.82 \%)$.

Ocypoda macrocera. On Day 6 there was an acceleration of ovarian development under 0.29 to $0.36 \mathrm{~g} \mathrm{cal}$ $\mathrm{cm}^{-2} \mathrm{~h}^{-1}$ light intensity. The increase in ovary protein $(+33.33 \%)$ was directly correlated to the drastic decrease of hepatopancreatic protein $(-44.58 \%)$. On the other hand, the haemolymph showed a marked increase $(+175.54 \%)$ of protein whereas muscle showed only a small rise $(+13.73 \%)$.

\section{Total free sugar (TFS)}

Ocypoda platytarsis. Ovarian TFS started increasing on Day $11(+20 \%)$ and continued so up to Day 16 $(+80 \%)$. There was a significant rise $(+266.67 \%)$ in the TFS level of the hepatopancreas up to Day 16 whereas the haemolymph TFS showed only a slight rise. In contrast, muscle TFS declined to a low level on
Days $6(-31.11 \%)$ and $11(-31.11 \%)$, although a rise accurred on Day $16(+100 \%)$.

Ocypoda macrocera. Ovarian TFS increased $(+25 \%)$ on Day 6 , as did hepatopancreas TFS content $(+25 \%)$; a corresponding decline occurred in muscle $(-80 \%)$ and haemolymph $(-24.75 \%)$.

Protein-bound sugar (PBS)

Ocypoda platytarsis. Ovarian PBS declined on Day 6 $(-55 \%)$ but maintained the same level as in controls on Days 11 and 16. PBS in hepatopancreas and muscles on Day 16 was the same as in controls. Haemolymph PBS decreased up to Day $11(-72.54 \%)$ but increased on Day $16(+28.69 \%)$.

Ocypoda macrocera. On Day 6, ovary PBS level $(-73.33 \%)$ and that in hepatopancreas $(-70 \%)$ showed a significant decline, in contrast to a slight rise in muscle $(+5 \%)$ and haemolymph $(+15.12 \%)$.

\section{Glycogen}

Ocypoda platytarsis. Glycogen in the ovary showed a rise throughout the experiment. It declined in hepatopancreas and muscle up to Day 11, whereas in the haemolymph it declined throughout the experiment, suggesting translocation to the ovary. Increase in ovary glycogen may be due to accumulation in connective tissue which is enormous in the ovary of $O$. platytarsis (Nadarajalingam 1983).

Ocypoda macrocera. Glycogen in the ovary increased on the Day $6(+287.50 \%)$. A similar increase occurred in haemolymph $(+111.11 \%)$ and hepatopancreas $(+50 \%)$. However, in muscle, the glycogen level declined $(-70 \%)$.

\section{Lipid}

Ocypoda platytarsis. Although no oogenetic activity was evident during the experiment, the ovary accumulated more lipid on Days $6(+950 \%), 11(+1350 \%)$ and $16(+1525 \%)$. A significant increase in lipid was noticed in the hepatopancreas throughout the experiment, but the haemolymph showed a steep decrease on Day $6(-13.93 \%)$ and $16(-42.86 \%)$.

Ocypoda macrocera. Lipid accumulated in the ovary on Day $6(+38.03 \%)$. A simultaneous lipid reduction was observed in hepatopancreas $(-43.96 \%)$, muscle $(-13.33 \%)$ and haemolymph $(-3.78 \%)$ suggesting lipid transfer to the ovary. 
Ribonucleic acid (RNA)

Ocypoda platytarsis. RNA content initially increased in the ovary on Day $6(+75 \%)$, but then declined Day $16(-12.50 \%)$. Such a RNA reduction coincided with oocyte resorption during this period. RNA content of haemolymph, hepatopancreas and muscles increased during the experiment except on Day 11 (hepatopancreas, $-14.29 \%$ ).

Ocypoda macrocera. A significant rise of RNA was observed in ovary $(+6.25 \%)$ and hepatopancreas $(+50 \%)$ on Day 6 with a fall in muscle $(-16.67 \%)$ and haemolymph $(-28.20 \%)$ on the same day.

\section{De-oxyribonucleic acid (DNA)}

Ocypoda platytarsis. Steep reduction in ovary DNA was noticed on Days $6(-66.67 \%)$ and $11(-33.33 \%)$. DNA increased in haemolymph, hepatopancreas and muscle on Days 11 and 16.

Ocypoda macrocera. A significant rise of DNA in the ovary occurred on Day $6(+300 \%)$ whereas the DNA level in haemolymph, hepatopancreas and muscle decreased.

\section{Survey of neuroendocrine centres}

Eyestalk of Ocypoda platytarsis

As in other decapod crustaceans, 3 major optic lobes in the eyestalk are the basal medulla terminalis, medulla interna, and medulla externa. A small budlike projection seen on the dorsolateral surface of the optic lobe is the sinus gland. There are 3 to 4 groups of neurosecretory cells (NSCs) in the medulla terminalis region constituting the medulla terminalis $\mathrm{X}$-organ $\left(\mathrm{MTX}_{1}\right.$ to $\left.\mathrm{MTX}_{4}\right)$. This agrees with the neurosecretory system of the eyestalk in Carcinus maenas (Smith \& Naylor 1972). Near the sinus gland associated with medulla terminalis, clusters of $\alpha$ type cells are seen. The $\alpha$ and $\beta$ type NSCs are associated with many sinuses near the medulla terminalis region. The $\alpha$ type cells showed more secretory activity than the $\beta$ type cells. The other small type NSC distributed in the Xorgan possessed scanty cytoplasm.

\section{Eyestalk of Ocypoda macrocera}

The eyestalk of $O$. macrocera is similar to that of $O$. platytarsis except for the smaller lobes and meagre longitudinal striated muscles in the corneal portion.
Brain of Ocypoda platytarsis

There are 5 types of cells, distinguished by size, shape and tinctorial properties.

A type cell. Cells measuring $1900 \mu^{2}$ are located on the periphery of antero-dorsal part of the brain. The nucleus is very large with an eccentric nucleolus. The cytoplasm is enormous, but the cell boundary is not distinct; cells are positive to CHP staining.

$A^{\prime}$ type cell. These are larger than the A type cell, measuring $2320 \mu \mathrm{m}^{2}$. They are unipolar with the axon end pointing towards the inner region of the brain. The broader end of the cell has a distinct nucleus and the cytoplasm is vacuolated.

B type cell. These are smaller axonless cells of size $1100 \mu \mathrm{m}^{2}$. They are very active and highly secretory during vitellogenesis. The nuclei are prominent with 2 nucleoli. The cytoplasm is coarse in appearance with a definite cell membrane. They are distributed in the proximal portion of the brain.

C type cell. The cytoplasm is meagre. The spherical nucleus has a dot-like nucleolus. The cell boundary is not distinct. The size of the cell is $192.5 \mu \mathrm{m}^{2}$.

$D$ type cell. These are smaller $\left(72.58 \mu \mathrm{m}^{2}\right)$. The cytoplasm is very scanty. A dot-like nucleolus is visible inside the nucleus. They are mostly phloxinophilic cells.

\section{Brain of Ocypoda macrocera}

In $O$. macrocera, 5 types of NSC are seen. They are $\mathrm{A}, \mathrm{A}^{\prime}, \mathrm{B}, \mathrm{C}$ and $\mathrm{D}$, and cell sizes are $1964 \mu^{2}, 2464$ $\mu \mathrm{m}^{2}, 1135 \mu \mathrm{m}^{2}, 201.15 \mu \mathrm{m}^{2}$ and $78.5 \mu \mathrm{m}^{2}$, respectively. The $\mathrm{A}$ and $\mathrm{A}^{\prime}$ type cells are bigger than those of $O$. platytarsis. The A type cells are very active when crabs are in second vitellogenesis. In ocypodid crabs, B type cells are highly secretory during ovarian maturation.

\section{Thoracic ganglion of $O$. platytarsis}

Four types of NSC are present in the thoracic ganglion.

A type cell. These are giant cells measuring $5028.8 \mu \mathrm{m}^{2}$. The cytoplasm is coarse and contains small vacuoles. Cell boundary is distinct and the CHP positive nucleus contains a large nucleolus.

$B$ type cell. These are smaller $\left(2828.7 \mu \mathrm{m}^{2}\right)$ than the A cell and found in clusters. They lack a definite cell boundary and the cytoplasm has small vacuoles. During the secretory cycle, the large nucleus loses its shape, but regains it after the release of neurosecretory materials. 
Table 3. Ocypoda platytarsis and Ocypoda macrocera. Quantitative analysis of biochemical constituents in ovary, hepatopancreas, muscle $\left(\mathrm{mg} \mathrm{mg}^{-1}\right.$ ) and haemolymph ( $\mathrm{mg} \mathrm{m}^{-1}$ )

\begin{tabular}{|c|c|c|c|c|c|c|c|}
\hline \multirow[t]{2}{*}{ Organ } & & \multicolumn{4}{|c|}{ O. platytarsis } & \multicolumn{2}{|c|}{ O. macrocera } \\
\hline & & \multirow{2}{*}{$\begin{array}{l}\text { Control } \\
\text { Day } 6\end{array}$} & \multicolumn{3}{|c|}{ Experimental } & $\begin{array}{l}\text { Control } \\
\text { Day } 6\end{array}$ & $\begin{array}{c}\text { Experimental } \\
\text { Day } 6\end{array}$ \\
\hline \multicolumn{7}{|l|}{ Protein } & \\
\hline & $\bar{X}(n)$ & $0.090(5)$ & $0.118(6)$ & $0.119(5)$ & $0.061(5)$ & $0.096(5)$ & $0.128(12)$ \\
\hline Ovary & $\begin{array}{c}\mathrm{SD} \\
\mathrm{t}\end{array}$ & $\begin{array}{l}0.004 \\
-\end{array}$ & $\begin{array}{l}0.028 \\
2.392^{\circ}\end{array}$ & $\begin{array}{l}0.028 \\
2.326^{\circ}\end{array}$ & $\begin{array}{l}0.009 \\
6.750^{\circ}\end{array}$ & $\begin{array}{l}0.015 \\
-\end{array}$ & $\begin{array}{l}0.023 \\
3.414^{\circ}\end{array}$ \\
\hline & $\bar{X}(n)$ & $0.071(3)$ & $0.058(6)$ & $0.077(5)$ & $0.058(4)$ & $0.083(4)$ & $0.046(12)$ \\
\hline Hepatopancreas & $\begin{array}{c}S D \\
t\end{array}$ & $\begin{array}{c}0.001 \\
-\end{array}$ & $\begin{array}{l}0.023 \\
1.422\end{array}$ & $\begin{array}{l}0.004 \\
3.850^{\circ}\end{array}$ & $\begin{array}{r}0.002 \\
12.395^{\circ}\end{array}$ & $\begin{array}{c}0.001 \\
-\end{array}$ & $\begin{array}{l}0.009 \\
6.738^{\circ}\end{array}$ \\
\hline Muscle & $\begin{array}{c}\bar{X}(n) \\
S D \\
t\end{array}$ & $\begin{array}{l}0.065(4) \\
0.014 \\
-\end{array}$ & $\begin{array}{l}0.089(6) \\
0.005 \\
3.191^{.}\end{array}$ & $\begin{array}{l}0.111(4) \\
0.001 \\
6.496^{.}\end{array}$ & $\begin{array}{l}0.081(4) \\
0.009 \\
1.926\end{array}$ & $\begin{array}{l}0.102(5) \\
0.011 \\
-\end{array}$ & $\begin{array}{l}0.116(12) \\
0.030 \\
1.402\end{array}$ \\
\hline Haemolymph & $\begin{array}{c}\bar{X}(n) \\
S D \\
t\end{array}$ & $\begin{array}{c}88.433(4) \\
3.472 \\
-\end{array}$ & $\begin{array}{c}184.473(6) \\
5.450^{\circ} \\
34.033^{\circ}\end{array}$ & $\begin{array}{c}111.749(4) \\
8.468 \\
5.095^{\circ}\end{array}$ & $\begin{array}{c}130.908(4) \\
8.769 \\
10.280^{\circ}\end{array}$ & $\begin{array}{c}63.177\{5\} \\
6.930 \\
-\end{array}$ & $\begin{array}{l}174.081(12) \\
14.445 \\
21.346^{\circ}\end{array}$ \\
\hline \multicolumn{8}{|c|}{ Total free sugar (TFS) } \\
\hline Ovary & $\begin{array}{l}\bar{X}(n) \\
S D \\
t\end{array}$ & $\begin{array}{l}0.0050(4) \\
0.0008 \\
-\end{array}$ & $\begin{array}{l}0.003(4) \\
0.002 \\
2.000\end{array}$ & $\begin{array}{l}0.006(4) \\
0.003 \\
0.667\end{array}$ & $\begin{array}{l}0.009(4) \\
0.001 \\
6.667^{\circ}\end{array}$ & $\begin{array}{l}0.004(4) \\
0.001 \\
-\end{array}$ & $\begin{array}{l}0.005(6) \\
0.002 \\
2.079\end{array}$ \\
\hline Hepatopancreas & $\begin{array}{c}\bar{X}(n) \\
S D \\
t\end{array}$ & $\begin{array}{l}0.0030(3) \\
0.0006 \\
-\end{array}$ & $\begin{array}{l}0.005(4) \\
0.001 \\
4.000^{\circ}\end{array}$ & $\begin{array}{l}0.008(4) \\
0.004 \\
2.500^{\circ}\end{array}$ & $\begin{array}{l}0.011(4) \\
0.003 \\
5.333^{*}\end{array}$ & $\begin{array}{l}0.004(4) \\
0.001 \\
-\end{array}$ & $\begin{array}{l}0.005(6) \\
0.002 \\
1.209\end{array}$ \\
\hline Muscle & $\begin{array}{c}\bar{X}(n) \\
S D \\
t\end{array}$ & $\begin{array}{l}0.0050(4) \\
0.0010 \\
\quad-\end{array}$ & $\begin{array}{l}0.003(4) \\
0.002 \\
2.000\end{array}$ & $\begin{array}{l}0.003(4) \\
0.002 \\
2.000\end{array}$ & $\begin{array}{l}0.010(4) \\
0.002 \\
4.984^{.}\end{array}$ & $\begin{array}{l}0.010(4) \\
0.001 \\
-\end{array}$ & $\begin{array}{l}0.002(6) \\
0.002 \\
7.873^{.}\end{array}$ \\
\hline Haemolymph & $\begin{array}{c}\bar{X}(n) \\
S D \\
t\end{array}$ & $\begin{array}{l}2.028(4) \\
0.043 \\
-\end{array}$ & $\begin{array}{l}1.861(4) \\
0.962 \\
0.248\end{array}$ & $\begin{array}{l}2.108(4) \\
0.223 \\
0.165\end{array}$ & $\begin{array}{l}2.042(4) \\
0.150 \\
0.029\end{array}$ & $\begin{array}{l}1.935(4) \\
0.558 \\
-\end{array}$ & $\begin{array}{l}1.456(6) \\
0.083 \\
1.596\end{array}$ \\
\hline \multicolumn{8}{|c|}{ Protein-bound sugar (PBS) } \\
\hline Ovary & $\begin{array}{c}\bar{X}(n) \\
S D \\
t\end{array}$ & $\begin{array}{l}0.002(4) \\
0.001 \\
-\end{array}$ & $\begin{array}{l}0.0009(4) \\
0.0001 \\
10.6070^{\circ}\end{array}$ & $\begin{array}{l}0.0020(4) \\
0.0008 \\
-\end{array}$ & $\begin{array}{l}0.002(3) \\
0.001 \\
-\end{array}$ & $\begin{array}{l}0.0030(3) \\
0.0006 \\
-\end{array}$ & $\begin{array}{l}0.0008(4) \\
0.0001 \\
5.3760^{\circ}\end{array}$ \\
\hline Hepatopancreas & $\begin{array}{c}\bar{X}(n) \\
S D \\
t\end{array}$ & $\begin{array}{l}0.003(4) \\
0.001 \\
-\end{array}$ & $\begin{array}{l}0.0007(4) \\
0.0002 \\
6.2840^{\circ}\end{array}$ & $\begin{array}{l}0.003(4) \\
0.001 \\
-\end{array}$ & $\begin{array}{l}0.003(4) \\
0.001 \\
-\end{array}$ & $\begin{array}{l}0.0020(3) \\
0.0007 \\
-\end{array}$ & $\begin{array}{l}0.0006(4) \\
0.0002 \\
2.9629\end{array}$ \\
\hline Muscle & $\begin{array}{c}\bar{X}(n) \\
S D \\
t\end{array}$ & $\begin{array}{l}0.002(4) \\
0.001 \\
-\end{array}$ & $\begin{array}{l}0.0020(3) \\
0.0006 \\
-\end{array}$ & $\begin{array}{l}0.0030(4) \\
0.0008 \\
3.3540^{\circ}\end{array}$ & $\begin{array}{l}0.002(3) \\
0.001 \\
-\end{array}$ & $\begin{array}{l}0.002(4) \\
0.001 \\
-\end{array}$ & $\begin{array}{l}0.0021(4) \\
0.0018 \\
0.1166\end{array}$ \\
\hline Haemolymph & $\begin{array}{c}\bar{X}(n) \\
S D \\
t\end{array}$ & $\begin{array}{l}2.325(4) \\
0.096 \\
-\end{array}$ & $\begin{array}{c}0.796(3) \\
0.195 \\
12.493^{\circ}\end{array}$ & $\begin{array}{c}0.639(4) \\
0.069 \\
28.610^{\circ}\end{array}$ & $\begin{array}{l}2.992(3) \\
0.204 \\
5.245^{\circ}\end{array}$ & $\begin{array}{l}0.688(4) \\
0.137 \\
-\end{array}$ & $\begin{array}{l}0.792(4) \\
0.216 \\
0.812\end{array}$ \\
\hline Glycogen & & & & & & & \\
\hline Ovary & $\begin{array}{c}\bar{X}(n) \\
S D \\
t\end{array}$ & $\begin{array}{l}0.0002(4) \\
0.0001 \\
-\end{array}$ & $\begin{array}{l}0.0004(4) \\
0.0001 \\
7.0130^{\circ}\end{array}$ & $\begin{array}{l}0.00060(4) \\
0.00008 \\
6.64700^{\circ}\end{array}$ & $\begin{array}{l}0.0006 \text { (4) } \\
0.0001 \\
5.5310^{\circ}\end{array}$ & $\begin{array}{l}0.0008(3) \\
0.0001 \\
-\end{array}$ & $\begin{array}{l}0.0031(4) \\
0.0013^{\circ} \\
3.8333^{\circ}\end{array}$ \\
\hline Hepatopancreas & $\begin{array}{c}\bar{X}(n) \\
S D \\
t\end{array}$ & $\begin{array}{l}0.0010(3) \\
0.0001 \\
-\end{array}$ & $\begin{array}{c}0.0006(4) \\
0.0001 \\
193.0570^{\circ}\end{array}$ & $\begin{array}{c}0.0005(4) \\
0.0001 \\
301.5030^{\circ}\end{array}$ & $\begin{array}{l}0.002(4) \\
0.001 \\
8.757^{.}\end{array}$ & $\begin{array}{l}0.001(3) \\
- \\
-\end{array}$ & $\begin{array}{l}0.0005(4) \\
0.0001 \\
-\end{array}$ \\
\hline
\end{tabular}


Table 3 (continued)

\begin{tabular}{|c|c|c|c|c|c|c|c|}
\hline \multirow{3}{*}{ Organ } & & \multicolumn{4}{|c|}{ O platytarsis } & \multicolumn{2}{|c|}{ O. macrocera } \\
\hline & & \multirow{2}{*}{$\begin{array}{l}\text { Control } \\
\text { Day } 6\end{array}$} & \multicolumn{3}{|c|}{ Experimental } & \multirow{2}{*}{$\begin{array}{l}\text { Control } \\
\text { Day } 6\end{array}$} & \multirow{2}{*}{$\begin{array}{c}\text { Experimenta } \\
\text { Day } 6\end{array}$} \\
\hline & & & Day 6 & Day 11 & Day 16 & & \\
\hline \multicolumn{8}{|c|}{ Glycogen (continued) } \\
\hline & $\bar{X}(n)$ & $0.0020(4)$ & $0.0007(4)$ & $0.0002(5)$ & $0.003(4)$ & $0.002(3)$ & $0.0006(4)$ \\
\hline \multirow[t]{3}{*}{ Muscle } & SD & 0.0001 & 0.0003 & 0.0001 & 0.001 & - & 0.0004 \\
\hline & $\mathrm{t}$ & - & $13.0000^{\circ}$ & 63.0000 & $5.000^{\circ}$ & - & $3.5737^{\circ}$ \\
\hline & $\bar{X}(n)$ & $0.265(3)$ & $0.154(4)$ & $0.049(4)$ & $0.093(3)$ & $0.072(4)$ & $0.1520(3)$ \\
\hline \multirow[t]{2}{*}{ Haemolymph } & $\mathrm{SD}$ & 0.008 & 0.024 & 0.011 & 0.008 & 0.008 & 0.0771 \\
\hline & $\mathrm{t}$ & - & $8.625^{\circ}$ & $30.190^{\circ}$ & $27.031^{\circ}$ & - & 1.8000 \\
\hline \multicolumn{8}{|l|}{ Lipid } \\
\hline & $\bar{X}(n)$ & $0.0040(4)$ & $0.042(4)$ & $0.058(5)$ & $0.065(4)$ & $0.071(3)$ & $0.098(4)$ \\
\hline \multirow[t]{3}{*}{ Ovary } & $\mathrm{SD}$ & 0.0006 & 0.007 & 0.010 & 0.008 & 0.009 & 0.025 \\
\hline & $t$ & - & $10.290^{*}$ & $12.698^{\circ}$ & $15.342^{*}$ & - & 2.000 \\
\hline & $\bar{X}(n)$ & $0.136(3)$ & $0.238(4)$ & $0.225(3)$ & $0.228(4)$ & $0.182(3)$ & $0.102(4)$ \\
\hline \multirow[t]{3}{*}{ Hepatopancreas } & $\mathrm{SD}$ & 0.009 & 0.016 & 0.018 & 0.017 & 0.010 & 0.083 \\
\hline & $\mathrm{t}$ & - & $10.921^{\circ}$ & $8.611^{\circ}$ & $9.296^{\circ}$ & - & 1.913 \\
\hline & $\bar{X}(n)$ & $0.008(4)$ & $0.010(4)$ & $0.013(4)$ & $0.001(4)$ & $0.015(3)$ & $0.0130(4)$ \\
\hline \multirow{3}{*}{ Muscle } & $\mathrm{SD}$ & 0.001 & 0.003 & 0.004 & 0.002 & 0.001 & 0.0008 \\
\hline & $\mathrm{t}$ & - & 2.050 & $2.532^{\circ}$ & $2.851^{\circ}$ & - & $3.6692^{\circ}$ \\
\hline & $\bar{X}(n)$ & $7.000(3)$ & $6.025(4)$ & $7.067(3)$ & $4.000(3)$ & $7.667(3)$ & $7.377(3)$ \\
\hline \multirow[t]{2}{*}{ Haemolymph } & $\mathrm{SD}$ & 1.000 & 1.506 & 1.007 & 1.000 & 0.577 & 0.671 \\
\hline & $t$ & - & 1.027 & 0.081 & $3.674^{\circ}$ & - & 0.568 \\
\hline \multicolumn{8}{|c|}{ Ribonucleic acid (RNA) } \\
\hline & $\bar{X}(n)$ & $0.008(4)$ & $0.014(4)$ & $0.008(4)$ & $0.007(4)$ & $0.0160(4)$ & $0.0170(8)$ \\
\hline \multirow[t]{3}{*}{ Ovary } & $\mathrm{SD}$ & 0.001 & 0.002 & 0.001 & 0.002 & 0.0008 & 0.0004 \\
\hline & $\mathrm{t}$ & - & $6330^{\circ}$ & & 1.054 & - & $2.7672^{\circ}$ \\
\hline & $\bar{X}(n)$ & $0.007(3)$ & $0.035(4)$ & $0.006(4)$ & $0.011(4)$ & $0.0060(4)$ & $0.009(7)$ \\
\hline \multirow[t]{3}{*}{ Hepatopancreas } & $\mathrm{SD}$ & 0.001 & 0.052 & 0.001 & 0.002 & 0.0008 & 0.001 \\
\hline & $\mathrm{t}$ & - & 1.077 & $2.408^{\circ}$ & $3.956^{\circ}$ & - & $6.389^{\circ}$ \\
\hline & $\bar{X}(n)$ & $0.0050(4)$ & $0.006(4)$ & $0.0050(4)$ & $0.0080(4)$ & $0.006(4)$ & $0.0050(8)$ \\
\hline \multirow[t]{2}{*}{ Muscle } & SD & 0.0001 & 0.001 & 0.0006 & 0.0008 & 0.001 & 0.0005 \\
\hline & $\mathrm{t}$ & - & $2.500^{\circ}$ & - & $7.5000^{\circ}$ & - & 1.0000 \\
\hline \multirow[t]{3}{*}{ Haemolymph } & $\bar{X}(n)$ & $0.355(3)$ & $0.579(4)$ & $0.444(4)$ & $0.509(4)$ & $0.305(4)$ & $0.219(6)$ \\
\hline & $\mathrm{SD}$ & 0.012 & 0.143 & 0.015 & 0.023 & 0.062 & 0.030 \\
\hline & $t$ & - & $3.093^{\circ}$ & $8.795^{\circ}$ & $11.666^{\circ}$ & - & $2.582^{\circ}$ \\
\hline \multicolumn{8}{|c|}{ Deoxyribonucleic acid (DNA) } \\
\hline & $\bar{X}(n)$ & $0.0030(4)$ & $0.0010(4)$ & $0.0020(4)$ & $0.003(4)$ & $0.00030(4)$ & $0.0012(7)$ \\
\hline Ovary & $\mathrm{SD}$ & 0.0006 & 0.0007 & 0.0005 & 0.001 & 0.00008 & 0.0088 \\
\hline & $\mathrm{t}$ & - & $5.0000^{*}$ & $2.5000^{\bullet}$ & - & - & $3.0000^{\circ}$ \\
\hline & $\bar{X}(n)$ & $0.0040(4)$ & $0.0030(4)$ & $0.0030(4)$ & $0.005(4)$ & $0.012(3)$ & $0.0050(6)$ \\
\hline Hepatopancreas & $\mathrm{SD}$ & 0.0006 & 0.0006 & 0.0008 & 0.001 & 0.002 & 0.0036 \\
\hline & $\mathrm{t}$ & - & $2.5000^{\circ}$ & - & $2.282^{\circ}$ & - & $3.9783^{\circ}$ \\
\hline & $\bar{X}(n)$ & $0.0003(3)$ & $0.0003(4)$ & $0.0010(4)$ & $0.001(3)$ & $0.0060(3)$ & $0.0003(5)$ \\
\hline Muscle & $\mathrm{SD}$ & 0.0001 & 0.0001 & 0.0005 & - & 0.0010 & 0.0002 \\
\hline & t & - & - & $3.8780^{\circ}$ & - & - & $10.4437^{\circ}$ \\
\hline & $\bar{X}(n)$ & $1.156(3)$ & $1.439(4)$ & $1.264(4)$ & $1.609(4)$ & $0.654(4)$ & $0.0035(4)$ \\
\hline Haemolymph & $\mathrm{SD}$ & 0.032 & 0.196 & 0.021 & 0.066 & 0.009 & 0.0013 \\
\hline & $\mathrm{t}$ & - & $2.836^{\circ}$ & $5.112^{\circ}$ & $11.982^{\circ}$ & - & $151.1736^{\circ}$ \\
\hline
\end{tabular}


Table 4. Ocypoda platytarsis. Relative rate of biochemical fluctuation in ovary, hepatopancreas, muscle and haemolymph as a response to increased light intensity. Values expressed in $\% \mathrm{mg} \mathrm{mg}^{-1}$ wet ovary, hepatopancreas and muscle; or $\% \mathrm{mg} \mathrm{ml}^{-1}$ wet haemolymph

\begin{tabular}{|c|c|c|c|c|c|c|c|c|c|c|c|c|}
\hline \multirow{2}{*}{$\begin{array}{l}\text { Biochemical } \\
\text { constituents }\end{array}$} & \multicolumn{3}{|c|}{ Ovary } & \multicolumn{3}{|c|}{ Hepatopancreas } & \multicolumn{3}{|c|}{ Muscle } & \multicolumn{3}{|c|}{ Haemolymph } \\
\hline & Day 6 & Day 11 & Day 16 & Day 6 & Day 11 & Day 16 & Day 6 & Day 11 & Day 16 & Day 6 & Day 11 & Day 16 \\
\hline Protein & +31.11 & +32.22 & -32.22 & -18.31 & +8.45 & -18.31 & +36.92 & +70.77 & +24.62 & +108.60 & +26.37 & +54.82 \\
\hline TFS & -40.00 & +20.00 & +80.00 & +66.67 & +116.67 & +266.67 & -31.11 & -31.11 & +100.00 & -8.23 & +3.94 & +0.69 \\
\hline PBS & -55.00 & - & - & -76.67 & - & - & - & +50.00 & - & -65.76 & -72.54 & +28.69 \\
\hline Glycogen & +100.00 & +200.00 & +200.00 & -40.00 & -50.00 & +100.00 & -65.00 & -90.00 & +50.00 & -41.89 & -81.51 & -64.91 \\
\hline Lipid & +950.00 & +1350.00 & +1525.00 & +75.00 & +65.44 & +67.65 & +25.00 & +62.50 & -87.50 & -13.93 & +0.96 & -42.86 \\
\hline RNA & +75.00 & - & -12.50 & +400.00 & -14.29 & +57.14 & +20.00 & - & +60.00 & +63.10 & +25.07 & +43.38 \\
\hline DNA & -66.67 & -33.33 & - & -25.00 & - & +25.00 & - & +233.33 & +233.33 & +24.48 & +9.34 & +39.19 \\
\hline
\end{tabular}

Table 5. Ocypoda macrocera. Relative rate of biochemical fluctuation in ovary, hepatopancreas, muscle and haemolymph in response to increased light intensity. Values expressed in $\% \mathrm{mg} \mathrm{mg}^{-1}$ wet ovary, hepatopancreas and muscle; or \% $\mathrm{mg} \mathrm{ml}^{-1}$ wet haemolymph

\begin{tabular}{|c|c|c|c|c|}
\hline $\begin{array}{l}\text { Biochemical } \\
\text { constituents }\end{array}$ & Ovary & Hepatopancreas & Muscle & Haemolymph \\
\hline Protein & +33.33 & -44.58 & +13.73 & +175.54 \\
\hline TFS & +25.00 & +25.00 & -80.00 & -24.75 \\
\hline PBS & -73.33 & -70.00 & +5.00 & +15.12 \\
\hline Glycogen & +287.50 & +50.00 & -70.00 & +111.11 \\
\hline Lipid & +38.03 & -43.96 & -13.33 & -03.78 \\
\hline RNA & +06.25 & +50.00 & -16.77 & -28.20 \\
\hline DNA & +300.00 & -58.33 & -95.00 & -99.46 \\
\hline
\end{tabular}

C type cell. These are small $\left(616.03 \mu \mathrm{m}^{2}\right)$ and have very little cytoplasm. They are spherical in shape. Nuclear materials are prominent.

$D$ type cell. These are very small and few in number. The nucleus is small and has a dot-like nucleolus. The size of the cell is $112.03 \mu \mathrm{m}^{2}$.

\section{Thoracic ganglion of Ocypoda macrocera}

Four types of NSC are present; they are smaller than those of $O$. platytarsis. They are A, B, C and D with sizes of $4898 \mu \mathrm{m}^{2}, 2639 \mu \mathrm{m}^{2}, 598 \mu \mathrm{m}^{2}$ and $102 \mu \mathrm{m}^{2}$, respectively. Among them $A$ and $B$ types show pronounced activity during ovarian maturation.

\section{Effect of elevated light intensity on neuroendocrine function and ovarian maturation}

In Ocypoda platytarsis, the ovary did not show any maturation on Days 6, 11 and up to 16 in crabs subjected to the increased light intensity of 0.29 to $0.36 \mathrm{~g} \mathrm{cal} \mathrm{cm}^{-2} \mathrm{~h}^{-1}$, whereas $O$. macrocera showed quicker ovarian maturation within $6 \mathrm{~d}$.

\section{Histological observations on crabs exposed to increased light intensity}

Ovary

In Ocypoda macrocera the ovary was fully occupied by yolk-laden vitellogenic oocytes which were encircled by small flattened follicle cells; however, in $O$. platytarsis, the ovary lacked maturing oocyte. Interestingly, the connective tissue as well as follicle cells were present in larger quantity and the few oocytes that were present in the ovary showed arrested growth.

\section{Eyestalk}

Ocypoda platytarsis. X-organ NSCs present in the medulla terminalis were found in a single group and the $\gamma$ cell types were hollow in appearance. The $\alpha$ and $\beta$ type cells were also highly secretory after the administration of elevated light intensity of 0.29 to 0.36 $\mathrm{g}$ cal $\mathrm{cm}^{-2} \mathrm{~h}^{-1}$. The sinus gland did not show any marked change.

Ocypoda macrocera. The cells in the X-organ were highly secretory. The $\alpha$ and $\beta$ types in the optic lobes 
showed more secretory activity as evidenced by the presence of basophilia in the perikaryon.

\section{Brain}

Ocypoda platytarsis. The NSCs in the brain were considerably reduced in size and gave only a blurred appearance on Day 16 of the experiment.

Ocypoda macrocera. The brain NSCs were highly secretory in nature. More nucleolar materials were also noticed in the perikaryon of the nucleus.

\section{Thoracic ganglion}

Ocypoda platytarsis. The thoracic ganglion appeared to be collapsed and considerably reduced in size.

Ocypoda macrocera. The NSCs of thoracic ganglion occurred in clusters and were more secretory, compared to brain NSCs. Many batches of cells, deeply staining with haematoxylin, were also CHP-positive. It thus seems that in O. macrocera the NSCs of brain and thoracic ganglion are highly secretory, and they seem to stimulate quicker ovarian maturation during experimental period.

\section{DISCUSSION}

Previous siudies deaiing with the influence of light on reproductive activities of crustaceans have used histomorphological changes in the ovary as main criteria (Paris \& Jenner 1952, Stephens 1952, Aiken 1969a, b, Perryman 1969, Rice \& Armitage 1974, Mocquard et al. 1976, Pradeille-Rouquette 1976a, b, Pillay \& Ono 1978, McQueen \& Steel 1980, Nelson et al. 1983, Quackenbush \& Herrnkind 1983, Aiken \& Waddy 1985). This study includes endocrinological and biochemical aspects.

Elevated DNA and RNA synthesis coupled with increased protein contents in the ovary of Ocypoda macrocera exposed to increased light intensities suggests oogonial proliferation, and early protein yolk synthesis in the oocyte. Protein biosynthesis in early vitellogenesis in crustacean oocytes has been indicated by several workers (see Adiyodi \& Subramoniam 1983). Besides protein and RNA increases, carbohydrate as well as lipid substances also showed elevated levels under increased light intensities in $O$. macrocera.

In Ocypoda platytarsis exposed to increased light intensities biochemical changes are restricted mainly to increases in carbohydrate components, such as glycogen and TFS, as well as in lipids which are metaboli- cally inert deutoplasmic substances. Nevertheless, RNA showed a slight increase on Day 6. Protein level also increased on Days 6 and 11, but showed a drastic reduction on Day 16. Histological examination of the ovary of $O$. platytarsis revealed augmented connective tissue formation, probably accounting for the increase in organic substances, especially the carbohydrate and lipids. On the other hand, DNA content consistently decreased during the experiment, suggesting the absence of oogonial proliferation; this is supported by histological findings. All these changes suggest that the ovary under increased light intensities responds at the nuclear level (DNA and RNA) in order to augment oogonial proliferation and early protein biosynthetic activity in $O$. macrocera. Conversely, the ovary of $O$. platytarsis remains unaltered to light changes with reference to oocyte development and maturation.

Translocation of yolk precursors from storage organs to vitellogenic ovary has been evidenced in several decapod crustaceans (Varadarajan \& Subramoniam 1982. Nadarajalingam 1983, Ezhilarasi \& Subramoniam 1984). The present investigation further suggests that under elevated light intensities, storage organs such as hepatopancreas, muscles and haemolymph exhibit sharp increases in their organic components in both crabs studied. However, such changes can be correlated to ovarian activity only in Ocypoda macrocera. Possibly, the elevated light conditions have a stimulatory effect on organic synthesis in the storage organs; irrespective of whcther they support ovarian maturation or not.

In Pachygrapsus marmoratus, normal vitellogenesis commences during short-day and low-temperature conditions, and becomes intense when photoperiod and temperature attain maximum values (PradeilleRouquette $1976 \mathrm{a}, \mathrm{b})$. Also in other crabs, such as Scylla serrata (Nagabhushanam \& Farooqui 1982) and Hemigrapus nudus (Knudsen 1964) increased length of photoperiod accelerates reproduction.

In Crustacea, eyestalk neurosecretory cells (NSCs), constituting the $\mathrm{X}$-organ sinus gland complex, mediate photoperiodic effects to other systems (Fingermann \& Oguro 1962, Konok 1962, Vitez 1973, Van Herp et al. 1977). In Palaemon serratus, Van Herp et al. (1977) found high secretory activity in the medulla externa and medulla terminalis ganglionaris X-organ (MTGX and MTGX $_{2}$ ) of eyestalks when the shrimp had been subjected to constant darkness or illumination with artificial daylight at an intensity of $0.29 \mathrm{~g} \mathrm{cal} \mathrm{cm}^{-2} \mathrm{~h}^{-1}$. In Orconectes virilis, longer photoperiods inhibit both synthesis and release of molt inhibiting hormones (MIH) from eyestalks whereas shorter photoperiods and constant darkness stimulates them (Aiken 1969a).

In the 2 crabs studied by us, cytological examination of the neurosecretory system of individuals exposed to 
high light intensities revealed marked differences between the 2 species. In the eyestalk, $\alpha$ and $\beta$ cells of both crabs showed hyperactivity under increased light intensity. Staining intensity was higher in NSCs, compared with that of normal crabs. The physiological effects of hyperactivity of eyestalk NSCs are not known; presumably, they are responsible for the general increase in organic components of ovary and other tissues.

Analysis of NSCs of brain and thoracic ganglia of both crabs, however, leads to a different picture. Ocypoda macrocera featured hyperactivity of its cells resulting in increased stainability, whereas $O$. platytarsis NSCs in brain and thoracic ganglia decreased, apparently arresting synthetic activities. It seems logical to infer that the neurosecretory hormones of brain and thoracic ganglia counteract the effects of eyestalk hormones thus bringing aboui dcceleration in the vitellogenic activities. Conversely, the inhibitory effect of high light intensity of the NSCs of brain and thoracic ganglion in Ocypoda platytarsis causes stagnation of oogenetic activities.

It has been postulated that the eyestalk hormones are antagonistic to brain and thoracic ganglia hormone in decapod crustaceans (Adiyodi \& Adiyodi 1970, Subramoniam 1981). Gomez (1965) and Gomez \& Nayar (1965) induced ovarian maturation in the juvenile and sexually inactive field crab Paratelphusa hydrodromous by implanting brain and thoracic ganglia respectively. Hinsch \& Bennet (1979) also found a similar effect using thoracic ganglia implants from mature crabs into the eyestalkless immature spider crab Libinia emarginata. Interestingly, eyestalk ablation alone did not induce precocious ovarian maturation in L. emarginata, suggesting an important role of ovary stimulating hormones from brain and thoracic ganglia.

The differential effect of light intensity on the ovarian functions of the 2 crabs studied may be traced back to their breeding behaviour under natural conditions. Ocypoda platytarsis had a near-continuous reproductive cycle without any peaks in the breeding intensity, whereas $O$. macrocera, though a continuous breeder, shows distinct breeding peaks during summer (May, Jun, Jul) when the temperature is high and the photoperiod long (Nadarajalingam 1983). It is, therefore, tempting to suggest from our results that $O$. macrocera responds positively to increasing light intensity, as it does under natural conditions; whereas such increase exerts no marked effect on $O$. platytarsis which is also insensitive to such conditions in nature.

Acknowledgements. The authors gratefully acknowledge financial assistance from U.G.C. grant No. F.23-1060/79 (SR.II). We thank Professor K. Ramalingam, Department of Zoology, for providing facilities and for his interest in our work, and Diane Cosgrove of Bodega Marine Laboratory, University of California, Davis, for her help in final manuscript preparation.

\section{LITERATURE CITED}

Adiyodi, K. G., Adiyodi, R. G. (1970). Endocrine control of reproduction in decapod Crustacea. Biol. Rev. 45: 121-165

Adiyodi, R. G., Subramoniam, T. (1983). Arthropoda-Crustacea. In: Adiyodi, K. G., Adiyodi, R. G. (ed.) Reproductive biology of invertebrates, Vol. 1. John Wiley and Sons Ltd., London, p. 443-495

Aiken, D. E. (1969a). Photoperiod, endocrinology, and the crustacean molt cycle. Science 164: 149-155

Aiken, D. E. (1969b). Ovarian maturation and egg laying in the cray fish Orconectes virilis: influence of temperature and photoperiod. Can. J. Zool. 47: 931-935

Aiken, D. E., Waddy, S. L. (1985). Photoperiodic control of vitellogenesis in the American lobster (Homarus americanus): comment on a recent report. Can. J. Fish. Aquat. Sci. 42: 198-199

Armitage, K. B., Buikema, A. L., Willems, N. J. (1973). The effect of photoperiod on organic constituents and molting of the cray fish Orconectes nais (Faxon). Comp. Biochem. Physiol. 44: 431-456

Bailey, N. T. J. (1959). Statistical methods in biology. English Universities Press Ltd., London

Carroll, W. V., Longley, R. W., Roe, J. H. (1956). The determination of glycogen in the liver and muscle by the use of anthrone reagent. J. biol. Chem. 220: 586-593

Ezhilarasi, S., Subramoniam, T (1984). Esterase activity in Scylla serrata (Forskal) during ovarian development. J. exp. mar. Biol. Ecol. 83: 1-12

Fingermann, M., Oguro, C. (1962). Alteration in the number of active neurosecretory cells in the eyestalk of the cray fish Orconectes clypeatus maintained in darkness. Am. Zool. 2: 283

Folch, J., Lee, S. M., Sloane-Stanley, G. H. (1957). A simple method for the isolation and purification of total lipids from animal tissues. J. biol. Chem. 266: 497-509

Giese, A. C., Pearse, J. S. (1974). Introduction. General principles. In: Giese, A. C., Pearse, J. S. (ed.) Reproduction of marine invertebrates, Vol. 1. Academic Press, New York, p. $1-49$

Gomez, R. (1965). Acceleration of development of gonads by implantation of brain in the crab, Paratelphusa hydro. dromous. Naturwissenschaften 9: 216

Gomez, R., Nayar, K. K. (1965). Certain endocrine influences in the reproduction of the crab, Paratelphusa hydrodromous. Zool. Jb. (Abt. Physiol.) 71: 694-701

Gomori, G. (1939). A differential stain for cell types in the pancreatic islets. Am. J. Pathol. 15: 497-499

Gomori, G. (1950). Aldehyde fuchsin: a new stain for elastic tissue. Am. J. Clin. Pathol. 20:665-666

Hinsch, G. W., Bennet, D. C. (1979). Vitellogenesis stimulated by thoracic ganglion implants into destalked immature spider crabs, Libinia emarginata. Tissue Cell 11. 345-451

Kinne, O. (ed.) (1970). Marine ecology, Vol. 1, Environmental factors, Part 1 . Wiley, London

Kinne, O. (ed.) (1971). Marine ecology, Vol. 1, Environmental factors, Part 2. Wiley, London

Kinne, O. (ed.) (1972). Marine ecology, Vol. 1, Environmental factors, Part 3 . Wiley, London

Knudsen, J. W (1964). Observations of the reproductive cy- 
cles and ecology of the common Brachyura and crab-like Anomura of the Puget Sound, Washington. Pacif. Sci. 18: $3-33$

Konok, I. (1962). Studies on the light and dark adaptation of the colour of the cray fish Astacus leptodactylus Eschscholz (Decapoda) controlled by the secretory activity of the central nervous system: II. Histomorphological picture of the neuroendocrine system related to the changes in illumination. Annal. Biol. Tihany 22: 27-37

Lowry, D. H., Rosebrough, N. J., Farr, F. L., Randall, R. J. (1951). Protein measurement with the folin phenol reagent. J. biol. Chem. 193: 265-275

McQueen, D. J., Steel, C. G. H. (1980). The role of photoperiod and temperature in the initiation of reproduction in the terrestrial isopod Oniscus asellus Linnaeus. Can. J. Zool. 58: 235-240

Merriam, H. G. (1971). Sensitivity of terrestrial isopod populations (Armadillidium) to food quality differences. Can. J. Zool. 49: 667-674

Mocquard, J. P., Besse, G., Juchault, P., Legrand, J. J., Martin, G., Picaud, J. L. (1976). Durée de la période de reproduction chez les femelles de l'Oniscoide Porcellio dilatatus Brandt suivant les conditions d'élevage: température, photopériode et groupment. Vie milieu 26: 51-76

Nadarajalingam, K. (1983). Reproductive biology of two semiterrestrial ocypodid crabs Ocypoda platytarsis $\mathrm{H}$. Milne Edwards and Ocypoda macrocera H. Milne Edwards (Brachyura, Ocypodidae) with reference to endocrine aspect of vitellogenesis. Ph.D. thesis, Madras Univ., Madras

Nagabhushanam, R., Farooqui, V. M. (1982). Influence of photoperiod on ovarian maturation of the marine crab (Scylla serrata). In: Subramoniam, T., Varadarajan, S. (ed.) Progress in invertebrate reproduction and aquaculture. Proceedings of the First All India Symposium on invertebrate reproduction. New Century Printers, Madras, p. $141-148$

iveison, K., Hedgecock, D., Borgeson, W. (1983). Photoperiodic and ecdysial control of vitellogenesis in lobsters (Homarus) (Decapoda, Nephropidae). Can. J. Fish. Aquat. Sci. 40: 940-947

Paris, O. H., Jenner, C. E. (1952). Photoperiodism in the fresh water shrimp, Palaemonectes paludosus (Gibbes). J. Elisha Mitchell Sci. Soc. 68: 144

Paris, O. H., Pitelka, F. A. (1962). Population characteristics of the terrestrial isopod Armadillidium vulgare in California grassland. Ecology 43: 229-248

Parvathy, K. (1970). Blood sugars in relation to chitin synthesis during cuticle formation in Emerita asiatica. Mar. Biol. 5: 108-112

Perryman, E. K. (1969). Procambarus simulans; light induced changes in neurosecretory cells and in ovarian cycle. Trans. Am. microsc. Soc. 8: $514-524$

Pillay, K. K., Ono, Y. (1978). The breeding cycles of two species of grapsid crabs (Crustacea, Decapoda) from the north coast of Kyushu, Japan. Mar. Biol. 45: 237-248

Pradeille-Rouquette, M. (1976a). Rôle de la photopériode dans la fonction de reproduction des femelles du crabe Pachygrapsus marmoratus (Fabricius). C.r. hebd. Séanc. Acad. Sci., Paris 282: 199-201

Pradeille-Rouquette, M. (1976b). Étude de la fonction de reproduction chez les femelles du crabe Pachygrapsus marmoratus (F.) et de différents facteurs qui lui sont liés. Cah. Biol. mar. 17: 387-403

Quackenbush, L. S., Herrnkind, W F. (1983). Regulation of the molt cycle of the spiny lobster, Panulirus argus: effect of photoperiod. Comp. Biochem. Physiol. 76: 259-263

Rice, P. R., Armitage, K. B. (1974). The influence of photoperiod on processes associated with molting and reproduction in the cray fish Orconectes nais (Faxon). Comp. Biochem. Physiol. 47: 243-259

Roe, J. H. (1955). The determination of sugar in blood and spinal fluid with anthrone reagent. J. biol. Chem. 20: 335-343

Searcy, D. G., Macinnis, A. J. (1970a). Determination of RNA by Dische and Orcinol technique. In: MacInnis, A. J., Voge, M. (ed.) Experiments and techniques in parasitology. W. H. Freeman and Co., San Francisco, p. 189-190

Searcy, D. G., MacInnis, A. J. (1970b). Determination of Burton diphenylamine technique. In: Macinnis, A. J., Voge, M. (ed.) Experiments and techniques in parasitology. W. H. Freeman and Co., San Francisco, p. 190-191

Segal, E. (1970). Light: invertebrates. In: Kinne, O. (ed.) Marine ecology, Vol. 1, Environmental factors, Part 1. Wiley, London, p. 59-211

Smith, G., Naylor, E. (1972). The neurosecretory system of the eyestalk of Carcinus maenas (Crustacea, Decapoda). J. Zool. 166: 313-321

Steele, V. J., Steel, D. H., Macpherson, B. R. (1977). The effect of photoperiod on the reproductive cycle of Gammarus setosus Dementieva, 1931. Crustaceana 4 (Suppl.): 58-63

Stephens, G. J. (1952). Mechanisms regulating the reproductive cycle in the cray fish, Cambarus. I. The female cycle. Physiol 7ool. 25: 70-84

Subramoniam, T. (1981). Sexual and reproductive endocrinology of Crustacea. J. scient. ind. Res. 40: 396-405

Van Herp, F., Bellon-Humbert, C., Luub, J. M., Wormhoudt, A. (1977). A histophysiological study of the eyestalk of Palaemon serratus (Pennant) with special reference to the impact of light and darkness. Archs. Biol. Paris 88: $257-278$

Varadarajan, S., Subramoniam, T. (1982). Biochemical changes during vitellogenesis in a hermit crab, Clibanarius clibanarius. In: Subramoniam, T, Varadarajan, S (ed.) Progress in invertebrate reproduction and aquaculture. Proceedings of the First All India Symposium on invertebrate reproduction. New Century Printers, Madras, p. $7-14$

Vitez, I. (1973). Histophysiological studies on the effect of environmental conditions on terrestrial isopodes. Annales, Sec. Biol. 13: 329-338

Weiser, W. (1963). Die Bedeutung der Tageslänge für das Einsetzen der Fortpflanzungsperiode bei Porcellio scaber Latr. (Isopoda). Z. Naturf. 18: 1090-1092 